\title{
INICJATYWA LOKALNA JAKO PRZYKŁAD KOPRODUKCJI USŁUG PUBLICZNYCH
}

\section{Abstract \\ Local initiative as an example of co-production of public services}

As a result of weaknesses of new public management and new public governance there is a search of the third way. One of the alternative is an idea of co-production of public services. In Polish circumstances it relates to local initiative. Author examine how this tool is implemented in cities associated in the Union of Polish Metropolis according to conducted research.

Keywords: co-production of public services, public management, public policy, social engagement

\section{Streszczenie}

Słabości nowego zarządzania publicznego oraz new public governance spowodowały poszukiwania tzw. trzeciej drogi. Jedną z możliwości jest idea współtworzenia usług publicznych, której polskim odpowiednikiem jest inicjatywa lokalna. Autor przedstawia stan realizacji tego narzędzia w miastach Unii Metropolii Polskich na podstawie badań kwestionariuszowych.

Słowa kluczowe: współtworzenie usług publicznych, zarządzanie publiczne, polityka publiczna, zaangażowanie społeczne

\section{Wprowadzenie}

W ostatnich latach w światowej debacie dotyczącej zarządzania publicznego widoczny jest wyraźny kryzys nowego zarządzania publicznego (new public management, dalej NPM) oraz wątpliwości związane z wdrażaniem współzarządzania publicznego (new public governance). Jak zauważył Dawid Sześciło, obecnie w debacie tej próżno szukać zdecydowanych obrońców NPM i gorliwych apologetów jego postulatów, aczkolwiek mogą być oni obecni na 
peryferiach tej debaty, w krajach takich jak Polska, które nie doświadczyły szerszej dyskusji teoretycznej na temat NPM ani praktycznej implementacji jego założeń [Sześciło, 2014: 56]. W przypadku współzarządzania krytyka koncentruje się na kwestii nieprzejrzystości relacji między aktorami polityki publicznej i na deficytach rozliczalności. Problem ten jest szczególnie podkreślany w ocenach funkcjonowania wielopoziomowego i złożonego modelu współzarządzania [Zawicki, 2015]. Pod wpływem tej krytyki zaczęły się formować nowe propozycje teoretyczne, których przykładem jest koprodukcja usług publicznych. Polega ona na tworzeniu tych ostatnich przy współudziale mieszkańców i lokalnej administracji, przy czym nie ogranicza się to wyłącznie do współpracy w ramach procesu podejmowania decyzji, ale dotyczy także wnoszenia swoich zasobów (materialnych, merytorycznych, informacyjnych, pracy) przez obie strony. Co istotne, koprodukcja nie jest wyłącznie partycypacją sprowadzającą się do procesu komunikacji. Jak zauważył D. Sześciło, przebudowa systemu usług publicznych w kierunku większej roli koprodukcji odzwierciedla próbę znalezienia drogi pomiędzy rynkowym a etatystycznym modelem zarządzania usługami publicznymi [Sześciło, 2015a]. Tym samym można wskazać trzy filary, na których opiera się idea koprodukcji: 1) partycypacja rozumiana jako współudział obywateli w formie i sposobie realizacji usług publicznych; 2) wymieszanie zasobów publicznych i prywatnych, co oznacza interakcję między administracją a zorganizowanymi grupami obywateli; 3) brak nastawienia na zysk uczestników oraz niekomercyjny charakter koprodukcji - co wyróżnia ten model, szczególnie na tle paradygmatu rynkowego [Sześciło, 2015b]. Na potrzeby niniejszego artykułu przyjęta zostanie definicja koprodukcji zaproponowana przez Johna Alforda. Określił on ją jako takie zachowania podmiotów nienależących do sfery publicznej, które są podejmowane wspólnie z instytucjami publicznymi, charakteryzują się dobrowolnością i mają na celu wytworzenie wartości publicznej [Alford, 2009].

Idea koprodukcji zadań publicznych wcale nie jest nowa. Jej początki związane są z koncepcją współtworzenia bezpieczeństwa publicznego, nad którą prace datuje się na przełom lat 60. i 70. Termin współtworzenia został zaproponowany podczas prac badawczych prowadzonych przez prof. Elinor Ostrom na Uniwersytecie w Indianie, mających wyjaśnić, dlaczego statystyki popełnianych w Stanach Zjednoczonych przestępstw systematycznie rosną (mimo wyposażenia policji w samochody i inne urządzenia techniczne), jak również dlaczego policja była bezbronna w sprawie zamieszek ulicznych w 1968 roku. Rezultatem badań E. Ostrom było sformułowanie koncepcji współtworzenia bezpieczeństwa w środowisku lokalnym jako warunku koniecznego do sprawnego funkcjonowania policji [Bovaird, Loeffler, 2016b]. Kryzys związany z upadkiem powszechnej wiary w rynek jako regulatora zachowań społecznych i w związku z tym NPM doprowadził do ponownej refleksji nad obowiązującym paradygmatem zarządzania. Poza kryzysem ekonomicznym do powrotu do niej skłaniały także problem rosnącego deficytu finansów publicznych, zagadnienie tzw. wicked problems czy kwestie, które nie mogą być skutecznie zarządzane wyłącznie przez sektor publiczny (problemy klimatyczne, bezpieczeństwa, ograniczeń sektora publicznego), 
jak również nowy charakter relacji między administracją publiczną a obywatelami, która określała tych ostatnich nie jako klientów, ale interesariuszy. W literaturze przedmiotu wskazuje się na różne przyczyny ponownego zainteresowania koprodukcją usług publicznych. Można wskazać rosnącą presję fiskalną, której poddawane były rządy w wielu krajach europejskich [Ciasullo i in., 2017; Meijer, 2016; Bovaird, 2012], a także coraz większe oczekiwania społeczne co do jakości realizowanych usług i dostosowania ich do lokalnych potrzeb [Ciasullo i in., 2017]. Co więcej, niektórzy badacze zwracali uwagę, że renesans idei współtworzenia usług publicznych był naturalną konsekwencją rozwoju paradygmatu governance, wraz z którym pojawiła się kwestia kapitału społecznego, współpracy administracji publicznej ze społecznościami lokalnymi czy wolontariatu [Bovaird, 2012; Podgórniak-Krzykacz, 2015; Meijer, 2016]. Nie bez znaczenia była także konieczność odbudowania zaufania do sektora publicznego, które po okresie kryzysu gospodarczego osiągało najniższe wskaźniki od lat. Jak zauważył Joost Fledderus:

[...] reformy wprowadzane z perspektywy koprodukcji miały na celu odbudowę zaufania do instytucji publicznych przez zmianę sposobu dostarczania usług publicznych. Było to zupełnie inne podejście w porównaniu z reformami opartymi na zasadach nowego zarządzania publicznego, które zasadzały się na założeniu racjonalnego wyboru i promowaniu efektywności ekonomicznej [Fledderus, 2015: 551]1.

Zaufanie do instytucji publicznych spadło niemal we wszystkich krajach. Co więcej, powszechne było przekonanie, że osoby sprawujące funkcje publiczne są cyniczne i dbają wyłącznie o swoje interesy [Stoker, 2006]. Bez względu na zakres przeprowadzanych reform sektora publicznego stałym trendem, który dało się zauważyć we wszystkich europejskich krajach, było odejście od logiki uwalniania zasobów (relieving logic), charakterystycznej dla zarządzania odgórnego (top down), w kierunku logiki upodmiatawiania (enabling logic), uważanej za otwartą na impulsy oddolne (bottom up), w którą wpisywała się koprodukcja usług publicznych [Bovaird, 2012; Witte, Geys, 2013]. W rezultacie problematyka koprodukcji usług publicznych zyskała duże zainteresowanie w takich obszarach jak służba zdrowia, opieka społeczna, bezpieczeństwo czy kultura i rozrywka [Ciasullo i in., 2017]. Realizowane w ten sposób usługi publiczne przyczyniają się nie tylko do pewnej elastyczności i większej efektywności funkcjonowania sektora publicznego, zyskują także członkowie społeczności lokalnej, którzy podczas koprodukcji usług publicznych uczą się pewnych umiejętności i narzędzi wspólnego działania. Sukces wspólnych działań utwierdza uczestników w przekonaniu, że jakość realizowanych usług jest również ich zasługą, a nie tylko bliżej nieokreślonych czynników zewnętrznych. Tym samym koprodukcja usług publicznych wpływa na wzrost poziomu zaufania do sektora publicznego [Fledderus, 2015].

${ }^{1}$ Przekład własny. 
Badacze zagadnienia koprodukcji usług publicznych zgodnie wyróżniają w jej ramach cztery rodzaje działań: 1) współzlecanie usług publicznych, które polega na angażowaniu mieszkańców w wybór i współtworzenie usług, np. fundusz sołecki; 2) współprojektowanie usług publicznych, którego idea polega na pozyskaniu pomysłów tworzenia tych usług i ich jednoczesnego dostarczania, np. opieki społecznej; 3) współdostarczanie usług publicznych, czyli wspólne działania mające na celu realizację pewnych usług, np. funkcjonowanie urządzeń użyteczności publicznych, dostępność instytucji publicznych; 4) współocena usług publicznych, czyli angażowanie mieszkańców oraz menadżerów publicznych w ocenianie usług i poziomu satysfakcji ich użytkowników [Bovaird, Loeffler, 2016a].

Przedmiotem niniejszego artykułu jest zbadanie, w jaki sposób problematyka koprodukcji usług publicznych realizowana jest w największych polskich miastach zrzeszonych w Unii Metropolii Polskich (UMP)². W tym celu skorzystano z następujących metod badawczych. Po pierwsze, na podstawie analizy dogmatyczno-prawnej zbadano treści uchwał miast UMP, aby stwierdzić, czy powołano inicjatywę lokalną. Po drugie, za pomocą metody ankietowej i wykorzystania kwestionariusza ankiety zbadano, jaka jest skala realizacji usług publicznych mierzona ilością środków przeznaczonych przez władze samorządowe na realizację tychże usług. Zbadano także, jaki rodzaj usług realizuje się w ramach tej inicjatywy i jakie czynniki wpływają na większe lub mniejsze zaangażowanie mieszkańców w realizację usług publicznych. Uzyskane informacje sprawdzono następnie za pomocą wywiadu telefonicznego z pracownikami urzędów odpowiedzialnych za zarządzanie inicjatywą lokalną. Badanie zostało przeprowadzone w czerwcu i lipcu 2016 roku we wszystkich miastach członkowskich Unii Metropolii Polskich. Wybór wskazanych miast wynikał z chęci poddania analizie w pierwszej kolejności największych miast znajdujących się na terenie kraju, które prowadzą współpracę z partnerami społecznymi w największym zakresie i dysponują największymi możliwościami finansowymi z racji wielkości posiadanego budżetu. Uzyskane w ten sposób wyniki przedstawiono w kolejnych częściach artykułu, który zakończono podsumowaniem zawierającym wskazanie najlepszych praktyk realizacji omawianej inicjatywy oraz rekomendacje do dalszego rozwijania tego narzędzia. Przeprowadzone badania mają charakter ewaluacyjny.

${ }^{2}$ Fundacja Unia Metropolii Polskich jest reprezentacją metropolii znajdujących się na terenie Polski. Została powołana w październiku 1990 roku. Jej członkami są: Gdańsk, Szczecin, Poznań, Bydgoszcz, Łódź, Warszawa, Wrocław, Kraków, Rzeszów, Lublin, Białystok. Przedstawiciel UMP jest członkiem strony samorządowej w Komisji Wspólnej Rządu i Samorządu Terytorialnego. 


\section{Inicjatywa lokalna jako przykład współtworzenia usług publicznych}

Narzędziem umożliwiającym urzeczywistnienie założeń koprodukcji usług publicznych w polskich warunkach prawnych jest m.in. inicjatywa lokalna. Przepisy prawne określające sposób jej realizacji zostały zawarte w ustawie o pożytku publicznym i o wolontariacie, a dokładnie w rozdziale 2a Inicjatywa lokalna (art. 19b-h). Instytucja ta w praktyce nazywana jest procedurą tzw. małych grantów lub procedurą uproszczona. Wprowadzenie tego rozwiązania miało na celu uelastycznienie dofinansowania realizacji zadań publicznych [Kosowski, 2012]. Inicjatywa lokalna polega na wsparciu przedsięwzięć realizowanych przez organizacje pozarządowe lub mieszkańców danej jednostki samorządu terytorialnego. Szczególne kryteria oraz tryb realizacji zadań w ramach tej inicjatywy określa organ stanowiący jednostki samorządowej w formie uchwały. Dyspozycja art. 19c wymienionej wyżej ustawy nakazuje każdej jednostce samorządu terytorialnego uchwalenie uchwały, wskazując jednocześnie, że szczegółowe kryteria oceny powinny uwzględniać przede wszystkim wkład pracy społecznej w realizację inicjatywy lokalnej. Wsparcia na realizację zadania udziela z kolei organ wykonawczy po uwzględnieniu złożonego przez uprawnione podmioty wniosku. Podstawą realizacji zadania jest umowa o wykonanie inicjatywy lokalnej podpisywana pomiędzy wnioskodawcą a organem wykonawczym jednostki samorządu terytorialnego. Wkład wnioskodawcy może obejmować świadczenie pracy społecznej albo świadczenie pieniężne lub rzeczowe. Dokumenty niezbędne do przeprowadzenia inicjatywy oraz jej harmonogram i kosztorys przygotowywane są wspólnie przez strony umowy. Wskazane regulacje zostały wprowadzone do systemu prawnego na podstawie Rządowego projektu ustawy o zmianie ustawy o działalności pożytku publicznego i o wolontariacie oraz niektórych innych ustaw (druk 1727). Jak zauważył wnioskodawca w uzasadnieniu do przygotowanego projektu ustawy, w formule wykonywania inicjatywy lokalnej należy przede wszystkim dopatrywać się aktywności obywateli jako jednostek zorganizowanych w stowarzyszeniu zwykłym oraz aktywizowania grup obywateli, którzy nigdy nie uczestniczyli w aktywności społecznej i budowaniu społeczeństwa obywatelskiego. Wykonywanie inicjatyw lokalnych powinno być elementem inkluzji obywatelskiej. Co więcej, jak zwrócił uwagę wnioskodawca w trakcie pierwszego czytania ustawy w sejmie:

Inicjatywy lokalne to próba nadania innego statusu podmiotom, które do tej pory funkcjonowały jako instytucje powoływane na okoliczność działań hobbystycznych, działań szczególnych z punktu zainteresowania samych członków. W przypadku stowarzyszeń zwykłych próbujemy wprowadzić instytucję inicjatywy lokalnej, która dawałaby tym organizacjom możliwość wchodzenia w relacje na podstawie umowy dla realizacji pewnych ważnych celów w tworzeniu infrastruktury społecznej i infrastruktury technicznej w środowisku lokalnym. Będzie to dowartościowanie pewnych podmiotów już istniejących, nadając im jednocześnie określony status możliwości 
realizacji wspólnych celów z samorządem terytorialnym na poziomie lokalnym, powiatowym i regionalnym. Inicjatywy lokalne to tak naprawdę usankcjonowanie obywatelskiej aktywności, inwencji obywatelskiej, która poprzez pewne procedury miałaby szansę na współuczestnictwo obywateli w tworzeniu infrastruktury społecznej i technicznej w środowisku lokalnym [Sprawozdanie..., 2009]³.

Wymienione wyżej motywacje wnioskodawcy wskazują, że ideą przewodnią była chęć wprowadzenia nowych narzędzi partycypacji społecznej i aktywności obywatelskiej. Problematyka realizacji usług publicznych w zasadzie w ogóle nie została zauważona. Inicjatywa lokalna miała być narzędziem służącym włączeniu niewielkich grup obywatelskich, nazywanych hobbystycznymi, do współpracy i realizacji ich własnych zamierzeń. Przygotowane przez ustawodawcę narzędzie nie uległo żadnym zmianom od czasu uchwalenia ustawy do chwili obecnej.

\section{Od zaangażowania po bierność}

Kilkuletni okres obowiązywania w obrocie prawnym instytucji inicjatywy lokalnej zachęca do tego, aby sprawdzić, w jaki sposób funkcjonuje ona w praktyce działania największych miast zrzeszonych w Unii Metropolii Polskich. W pierwszej kolejności istotne jest zbadanie stanu faktycznego, a zatem tego, w ilu miastach wdrożono wymagane regulacje prawne i na tej podstawie podjęto działania.

Wykorzystując informacje przedstawione powyżej, można stwierdzić, że pomimo obowiązku prawnego przyjęcia w drodze uchwały szczegółowych zasad i kryteriów realizacji inicjatywy lokalnej nie wszystkie miasta wywiązały się z niego. Cztery miasta w ogóle nie podjęły inicjatywy legislacyjnej w tej sprawie i w rezultacie nie zrealizowały żadnego zadania. Warto jednocześnie podkreślić, że w przypadku pozostałych miast w ramach procedury inicjatywy lokalnej zostało zrealizowane przynajmniej jedno zadanie. W niektórych przypadkach był to tylko jeden projekt (Kraków). Liderem pod względem liczby zrealizowanych inicjatyw jest Poznań, który przeprowadził aż 87 takich projektów, następnymi miastami są Warszawa i Katowice.

Zaprezentowane dane warto zestawić z wartością realizowanych projektów. Zasadnicze znaczenie ma bowiem to, czy przeprowadzone inicjatywy lokalne, czyli współpraca pomiędzy mieszkańcami a administracją lokalną, były doraźne i dotyczyły niewielkich projektów, czy też w ich wyniku zrealizowano większe przedsięwzięcia inwestycyjne. A zatem czy mieszkańcy byli gotowi do ponoszenia większych wydatków na realizację usług publicznych, czy też jedynie doraźnych inicjatyw. Wykres 1 przedstawia zestawienie uzyskanych informacji.

3 Więcej na temat sejmowego procesu legislacyjnego związanego z Rządowym projektem ustawy o zmianie ustawy o działalności pożytku publicznego i o wolontariacie oraz niektórych innych ustaw, na podstawie którego wprowadzono instytucję inicjatywy lokalnej - zob. http://orka.sejm.gov. pl/SQL.nsf/poskomprocall?OpenAgent\&6\&1727 [dostęp: 4.10.2017]. 
Tabela 1

Liczba inicjatyw lokalnych zrealizowanych w miastach UMP

\begin{tabular}{|c|l|c|c|c|c|c|}
\hline \multirow{2}{*}{ L.P. } & \multirow{2}{*}{ Miasto } & \multirow{2}{*}{$\begin{array}{c}\text { Uchwaly } \\
\text { regulujące }\end{array}$} & \multicolumn{2}{|c|}{ Liczba zrealizowanych inicjatyw } & \multirow{2}{*}{ Suma } \\
\cline { 4 - 6 } & & $\mathbf{2 0 1 4}$ & $\mathbf{2 0 1 5}$ & $\mathbf{2 0 1 6}$ & \\
\hline 1 & Bydgoszcz & tak $^{1}$ & 8 & 11 & 10 & $\mathbf{2 9}$ \\
\hline 2 & Szczecin & nie & 0 & 0 & 0 & $\mathbf{0}$ \\
\hline 3 & Warszawa & tak $^{2}$ & 9 & 30 & 39 & $\mathbf{7 8}$ \\
\hline 4 & Katowice & tak $^{3}$ & 6 & 18 & 29 & $\mathbf{5 3}$ \\
\hline 5 & Lódź & tak $^{4}$ & 2 & 3 & 6 & $\mathbf{1 1}$ \\
\hline 6 & Białystok & nie $^{2}$ & 0 & 0 & 0 & $\mathbf{0}$ \\
\hline 7 & Kraków & tak $^{5}$ & 0 & 0 & 1 & $\mathbf{1}$ \\
\hline 8 & Rzeszów & nie $^{2}$ & 0 & 0 & 0 & $\mathbf{0}$ \\
\hline 9 & Lublin & tak $^{6}$ & 0 & 0 & 10 & $\mathbf{1 0}$ \\
\hline 10 & Wrocław & tak $^{7}$ & 4 & 6 & 2 & $\mathbf{1 2}$ \\
\hline 11 & Poznańn & tak $^{8}$ & 37 & 21 & 29 & $\mathbf{8 7}$ \\
\hline 12 & Gdańsk & tak $^{9}$ & 0 & 0 & 0 & $\mathbf{0}$ \\
\hline \multicolumn{2}{|c|}{ Suma } & & 66 & 89 & 126 & $\mathbf{2 8 1}$ \\
\hline
\end{tabular}

${ }^{1}$ Uchwała nr XXXIII/692/212 Rady Miasta Bydgoszczy z dnia 31 października 2012 r. w sprawie trybu i szczegółowych kryteriów oceny wniosków o realizację zadania publicznego w ramach inicjatywy lokalnej.

${ }^{2}$ Uchwała nr LXI/1692/2013 Rady Miasta Stołecznego Warszawy z dnia 11 lipca 2013 r. w sprawie określenia trybu i szczegółowych kryteriów oceny wniosków o realizację zadania publicznego w ramach inicjatywy lokalnej.

${ }^{3}$ Uchwała nr XXXII/659/16 Rady Miasta Katowice z dnia 23 listopada 2016 r. w sprawie trybu i szczegółowych kryteriów oceny wniosków o realizację zadań publicznych w ramach inicjatywy lokalnej.

${ }^{4}$ Uchwała nr XCIV/1986/14 Rady Miejskiej w Łodzi z dnia 8 października 2014 r. w sprawie określenia trybu i szczegółowych kryteriów oceny wniosków o realizację zadania publicznego w ramach inicjatywy lokalnej.

${ }^{5}$ Uchwała nr LXXXI/1969/17 Rady Miasta Krakowa z dnia 30 sierpnia 2017 r. w sprawie określenia trybu i szczegółowych kryteriów oceny wniosków o realizację zadania publicznego w ramach inicjatywy lokalnej.

${ }^{6}$ Uchwała nr 156/XLIII/2014 Rady Miasta Lublin z dnia 4 września 2014 r. w sprawie określenia trybu i szczegółowych kryteriów oceny wniosków o realizację zadania publicznego w ramach inicjatywy lokalnej.

${ }^{7}$ Uchwała nr LIV/1554/10 Rady Miejskiej Wrocławia z dnia 9 września 2010 r. w sprawie określenia trybu i szczegółowych kryteriów oceny wniosków o realizację zadania publicznego w ramach inicjatywy lokalnej (Dziennik Urzędowy Województwa Dolnośląskiego z 11 października $2010 \mathrm{r}$. Nr 189, poz. 2828).

${ }^{8}$ Uchwała nr VIII/66/VI/2011 Rady Miasta Poznania z dnia 22-03-2011 w sprawie trybu i szczegółowych kryteriów oceny wniosków o realizację zadania publicznego w ramach inicjatyw lokalnych.

${ }^{9}$ Uchwała nr XXVIII/757/16 Rady Miasta Gdańska z dnia 25 sierpnia 2016 r. w sprawie określenia trybu i szczegółowych kryteriów oceny wniosków o realizację zadania publicznego w ramach inicjatywy lokalnej.

Źródło: opracowanie własne. 


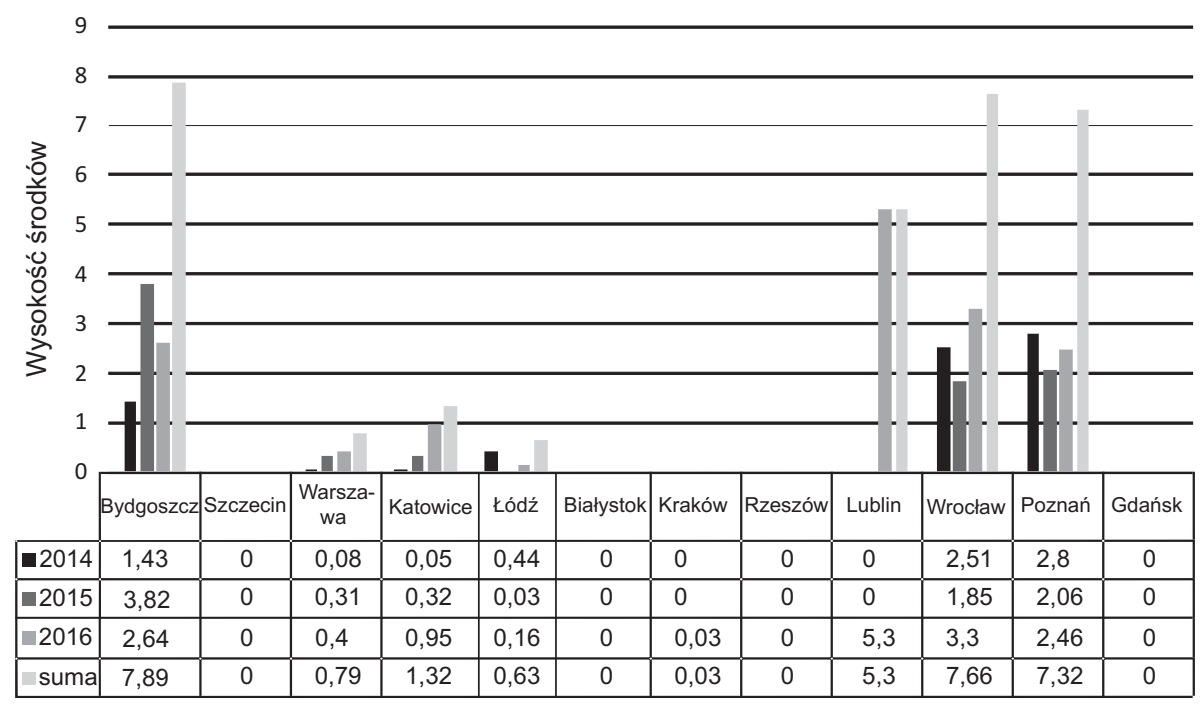

2014 - 2015 - 2016 Suma

Wykres 1. Wysokość środków przeznaczonych na realizację inicjatywy lokalnej (w mln zł)

Źródło: opracowanie własne na podstawie własnych badań.

Przedstawione dane pokazują, że liczba zrealizowanych inicjatyw lokalnych nie jest powiązana z ilością wydanych środków finansowych. Jeśli bowiem uwzględni się sumę pieniędzy, jaka została wydana na koprodukcję usług publicznych, lista liderów kształtuje się zupełnie inaczej niż w zestawieniu zaprezentowanym w tabeli 1. Zdecydowanymi liderami są trzy miasta - Bydgoszcz, Wrocław i Poznań, które w ciągu ostatnich trzech lat na usługi realizowane w ramach inicjatywy lokalnej wydały ponad $7 \mathrm{mln}$ zł. Kolejnym miastem jest Lublin, który tylko w 2016 roku wydał kwotę $5,3 \mathrm{mln}$ zł, a pozostałe miasta przeznaczyły na ten cel poniżej $1,3 \mathrm{mln}$ zł. Oznacza to, że w większości miast UMP inicjatywa lokalna wykorzystywana jest do realizacji niewielkich projektów, w których zaangażowanie finansowe obu stron jest wręcz symboliczne. Jedynie w przypadku czterech miast, które są liderami w tej kategorii, można mówić o istotnym finansowym zaangażowaniu, które czasami może oznaczać realizację mniejszej liczby projektów, ale za to o znacznie większym zaangażowaniu stron.

W tym miejscu warto poszukać potencjalnych czynników, które mogą mieć wpływ na zakres realizacji inicjatywy lokalnej. Jednym z nich może być sposób komunikacji prowadzonej przez administrację lokalną, a zatem promocji rozwiązań wśród mieszkańców potencjalnie zainteresowanych koprodukcją.

Na podstawie danych przedstawionych na wykresie 2 można stwierdzić, że wskazane różnice są niewielkie. W miastach UMP, w których przyjęto uchwałę dotyczącą inicjatywy lokalnej, powszechnie stosowanym narzędziem jest strona internetowa urzędu. Pozostałe narzędzia komunikacji są wykorzystywane w mniejszym zakresie, jednakże również bardzo często. 


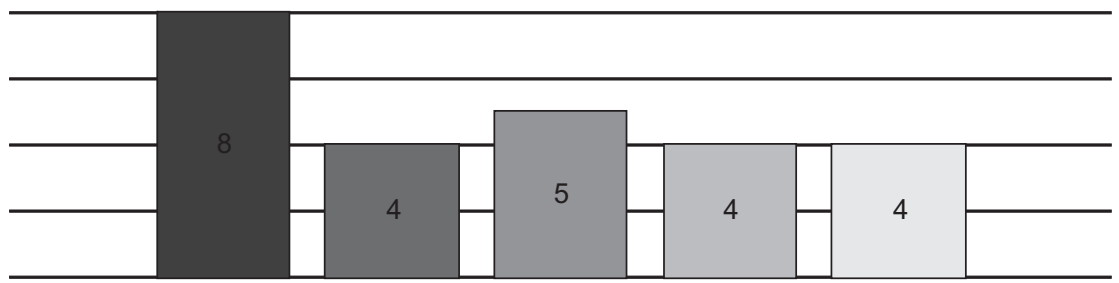

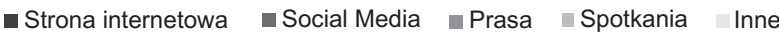

Wykres 2. Narzędzia prowadzenia promocji

Źródło: opracowanie własne na podstawie własnych badań.

Ważnym elementem oceny charakteru realizowanych wniosków w ramach inicjatywy lokalnej jest okres ich realizacji. Dotyczy to gotowości mieszkańców do systematycznego współfinansowania usług publicznych, a nie jedynie doraźnego wydatku. W celu zbadania tej kwestii sprawdzono, ile projektów spośród wszystkich realizowanych w miastach UMP obejmowało okres odpowiednio: do 2 lat, od 2 do 4 lat, od 4 do 6 lat lub powyżej 6 lat.

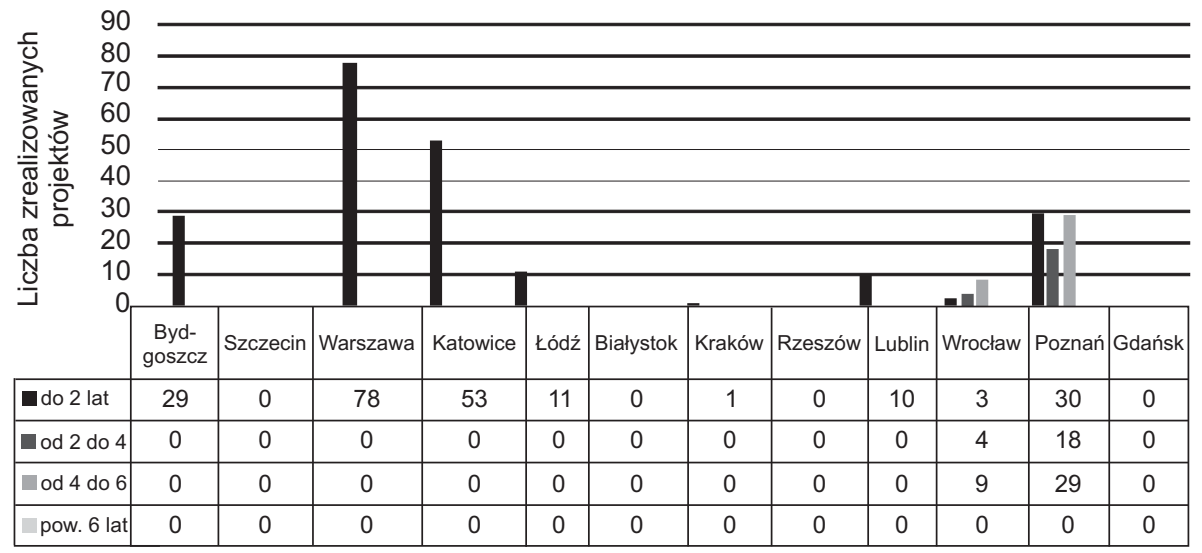

Wykres 3. Okres realizacji inicjatyw lokalnych

Źródło: opracowanie własne na podstawie własnych badań.

Na podstawie danych przedstawionych na wykresie 3 można stwierdzić, że zdecydowana większość projektów, bo aż 215, była realizowana w okresie do 2 lat. Spośród wszystkich 281 projektów realizowanych w miastach UMP jedynie 22 były realizowane w okresie od 2 do 4 lat, a $38 \mathrm{w}$ przedziale od 4 do 6 lat. Żaden projekt nie wykraczał poza ten horyzont czasowy. Tym samym należy uznać, że inicjatywa lokalna jest narzędziem wykorzystywanym do realizacji krótkotrwałych projektów. 


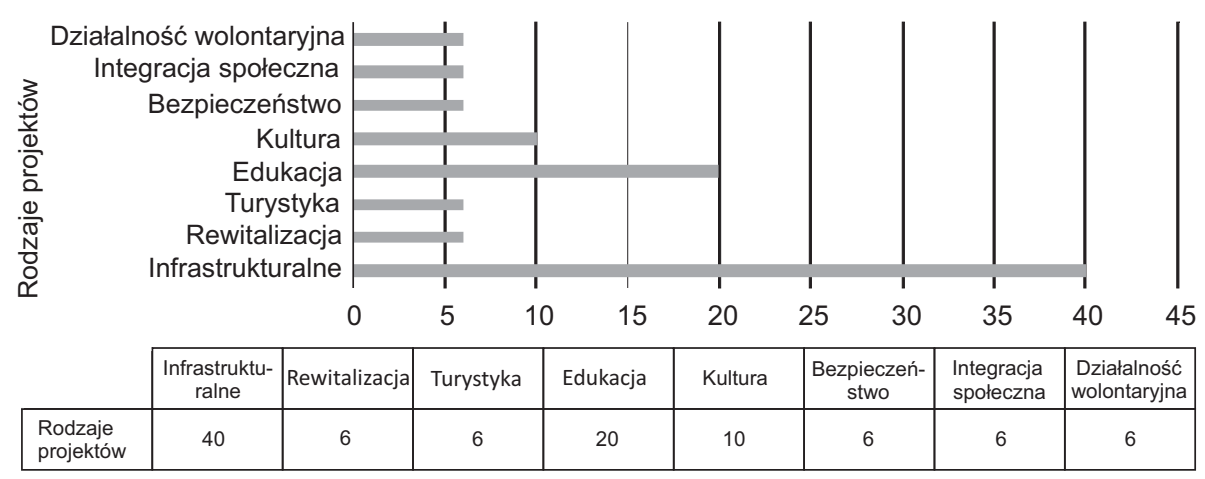

Wykres 4. Rodzaje projektów realizowanych w ramach inicjatywy lokalnej (\%)

Źródło: opracowanie własne na podstawie własnych badań.

Ostatnim elementem analizy instytucji inicjatywy lokalnej jest zakres przedmiotowy realizowanych projektów.

Na podstawie danych ukazanych na wykresie 4 można stwierdzić, że największą część realizowanych projektów stanowią te infrastrukturalne. Niemal co drugi projekt dotyczy właśnie tego obszaru. Pozostałe działania to edukacja i kultura, które realizowane są odpowiednio w 20 i 10 procentach. Wskazane dane są istotne w kontekście tego, jakie potrzeby motywują mieszkańców do zaangażowania się, często finansowego, w realizację usług publicznych. Zdecydowana przewaga projektów infrastrukturalnych pokazuje, że głównie codzienne potrzeby - poprawa stanu dróg i chodników, z których na co dzień korzystamy - są czynnikiem zachęcającym do współpracy. W związku z powyższym warto uwzględnić ten element w komunikacji z mieszkańcami i promocji instytucji inicjatywy lokalnej, aby zwiększyć zakres jej wykorzystania.

\section{Wnioski}

Koprodukcja usług publicznych nie pozwoli oczywiście rozwiązać wszystkich problemów zarządzania tymi usługami. Niemniej jednak umożliwia realizowanie zadań nie tylko z perspektywy sektora publicznego, ale także wspólnej odpowiedzialności członków społeczności lokalnej. Przykład polskich miast z UMP potwierdza tezę badaczy tego narzędzia, że pomimo 30 lat dużego zainteresowania koprodukcją zadań publicznych cały czas nie staje się ona głównym sposobem na realizację usług publicznych. Dominują przede wszystkim działania o małej skali, które są jedynie uzupełnieniem tradycyjnych form funkcjonowania sektora publicznego [Bovaird, Loeffler, 2016a]. Inicjatywa lokalna jest narzędziem stosowanym przez większość miast UMP w ograniczonym stopniu. W wielu z nich liczba realizowanych projektów pozostaje na niskim poziomie. Trudno obecnie ocenić, co jest czynnikiem decydującym o tym, dlaczego tak się dzieje - czy jest 
to kwestia niewielkiej promocji tej instytucji, a zatem małej wiedzy mieszkańców na temat tego narzędzia finansowania usług publicznych, czy też niewielkie zaangażowanie mieszkańców. Przykłady takich miast jak Poznań, Wrocław i Bydgoszcz wskazują, że budżet realizowanych zadań systematycznie rośnie i może osiągać w perspektywie kilku lat nawet ponad $7 \mathrm{mln}$ zł. Tym samym istnieje spora przestrzeń do zaangażowania zasobów mieszkańców do realizacji zadań publicznych. Zbadania wymaga wciąż jeszcze kwestia prowadzonych działań informacyjnych - na ile wpływają one na popularność inicjatywy lokalnej wśród mieszkańców oraz wymiar finansowy realizowanych projektów. Odpowiedź na to pytanie wymagałaby przeprowadzenia pogłębionych badań wśród mieszkańców, którzy zaangażowali się w inicjatywę lokalną. Pozwoliłyby one ustalić, co skłoniło mieszkańców do wydatkowania własnych środków. Szczególnie ciekawy jest przykład Poznania, w którym duża część projektów była realizowana w przedziale czasowym do 4 i do 6 lat. W perspektywie badań nad instytucją inicjatywy lokalnej warto byłoby sprawdzić, jakie czynniki skłoniły mieszkańców do zaangażowania się finansowo w projekty na tak długi czas. Tym bardziej że poza wymiarem finansowym i sporymi oszczędnościami dla budżetu jednostek samorządu terytorialnego istotna jest wartość dodana tych projektów. Przejawia się ona w budowaniu kapitału społecznego wśród mieszkańców, wspólnym doświadczeniu działania, a także zdobyciu wiedzy na temat sposobu funkcjonowania administracji lokalnej i realizowanych przez nią zadań. Warto również podkreślić, że liczba realizowanych projektów w ramach inicjatywy lokalnej w miastach UMP rośnie z roku na rok. Analiza danych tylko z ostatnich trzech lat wyraźnie pokazuje, jak rozwijał się ten trend: 66, 89 i 126 - to liczby projektów odpowiednio z lat $2014,2015,2016$. Systematyczny wzrost liczby zrealizowanych projektów pozwala mieć nadzieję, że w najbliższym czasie inicjatywa lokalna stanie się coraz popularniejszym, a być może trwale wpisanym w proces partycypacji narzędziem.

Na podstawie przeanalizowanych projektów warto zwrócić uwagę także na kwestię okresu obowiązywania uchwał regulujących sposób funkcjonowania inicjatyw lokalnych. Największa liczba projektów została zrealizowana w miastach, w których stosowne akty prawa miejscowego zostały przyjęte najwcześniej. W związku z powyższym kolejnym postulatem badawczym jest sprawdzenie, jak w ramach innych jednostek samorządu terytorialnego długość obowiązywania regulacji prawnych wpływa na zakres realizowanych regulacji.

\section{Bibliografia}

\section{Akty prawne}

Rządowy projekt ustawy o zmianie ustawy o działalności pożytku publicznego i o wolontariacie oraz niektórych innych ustaw (druk 1727).

Uchwała nr XXXIII/692/212 Rady Miasta Bydgoszczy z dnia 31 października 2012 r. w sprawie trybu i szczegółowych kryteriów oceny wniosków o realizację zadania publicznego w ramach inicjatywy lokalnej. 
Uchwała nr XXVIII/757/16 Rady Miasta Gdańska z dnia 25 sierpnia 2016 r. w sprawie określenia trybu i szczegółowych kryteriów oceny wniosków o realizację zadania publicznego w ramach inicjatywy lokalnej.

Uchwała nr XXXII/659/16 Rady Miasta Katowice z dnia 23 listopada 2016 r. w sprawie trybu i szczegółowych kryteriów oceny wniosków o realizację zadań publicznych w ramach inicjatywy lokalnej.

Uchwała nr LXXXI/1969/17 Rady Miasta Krakowa z dnia 30 sierpnia 2017 r. w sprawie określenia trybu i szczegółowych kryteriów oceny wniosków o realizację zadania publicznego w ramach inicjatywy lokalnej.

Uchwała nr 156/XLIII/2014 Rady Miasta Lublin z dnia 4 września 2014 r. w sprawie określenia trybu i szczegółowych kryteriów oceny wniosków o realizację zadania publicznego w ramach inicjatywy lokalnej.

Uchwała nr VIII/66/VI/2011 Rady Miasta Poznania z dnia 22-03-2011 w sprawie trybu i szczegółowych kryteriów oceny wniosków o realizację zadania publicznego w ramach inicjatyw lokalnych.

Uchwała nr LXI/1692/2013 Rady Miasta Stołecznego Warszawy z dnia 11 lipca 2013 r. w sprawie określenia trybu i szczegółowych kryteriów oceny wniosków o realizację zadania publicznego w ramach inicjatywy lokalnej.

Uchwała nr XCIV/1986/14 Rady Miejskiej w Łodzi z dnia 8 października 2014 r. w sprawie określenia trybu i szczegółowych kryteriów oceny wniosków o realizację zadania publicznego w ramach inicjatywy lokalnej.

Uchwała nr LIV/1554/10 Rady Miejskiej Wrocławia z dnia 9 września 2010 r. w sprawie określenia trybu i szczegółowych kryteriów oceny wniosków o realizację zadania publicznego w ramach inicjatywy lokalnej (Dziennik Urzędowy Województwa Dolnośląskiego z 11 października 2010 r. Nr 189, poz. 2828).

Ustawa z dnia 24 kwietnia 2003 roku o pożytku publicznym i o wolontariacie, Dz.U. z 2003 r. Nr 96 poz. 873.

\section{Opracowania}

Alford J. (2009), Engaging Public Sector Clients: From Service-Delivery to Co-Production, Palgrave Macmillan, London.

Bovaird T. (2012), We're All in This Together: User and Community Co-Production of Public Outcomes, A Discussion Paper, Institute of Local Government Studies, University of Birmingham.

Bovaird T., Loeffler E. (eds.) (2016a), Public Management and Governance, Routledge, New York.

Bovaird T., Loeffler E. (2016b), User and Community: Co-Production of Public Services: What Does the Evidence Tell Us?, „Internation Journal of Public Administration”, 39(13).

Ciasullo M.V., Palumbo R., Troisi O. (2017), Reading Public Service Co-Production Through the Lenses of Requisite Variery, „International Journal of Business and Management”, $12(2)$

Fledderus J. (2015), Building Trust Through Public Service Co-Production, „International Journal of Public Sector Management", 28(7). 
Kosowski J. (2012), Wspótpraca jednostek samorzqdu terytorialnego z organizacjami pozarzadowymi, Lex a Wolters business, Warszawa.

Meijer A. (2016), Co-Production as a Structural Transformation of the Public Sector, „International Journal of Public Sector Management”, 29(6).

Podgórniak-Krzykacz A. (2015), Co-Production for Local Public Services - a Case Study of the Cooperative Hallenbad Nörten-Hardenberg eG, „Zarządzanie Publiczne” (Kraków), 2(30).

[Sprawozdanie z prac Komisji Polityki Społecznej i Rodziny z 9 marca 2009 r.], http://orka. sejm.gov.pl/Biuletyn.nsf/wgskrnr6/PSR-137 [dostęp: 4.10.2017].

Stoker G. (2006), Why Politics Matters? Making Democracy Work, Palgrave Macmillan, London.

Sześciło D. (2014), Rynek, prywatyzacja, interes publiczny. Wyzwania urynkowienia ustug publicznych, Wydawnictwo Naukowe Scholar, Warszawa.

Sześciło D. (2015a), W poszukiwaniu trzeciej drogi - poza etatystycznym i rynkowym modelem ustug publicznych, http://zarzadzaniepubliczne.pl/download/dr/20150422-DS.pdf [dostęp: 4.10.2017].

Sześciło D. (2015b), Współzarzqdzanie jako koprodukcja usług publicznych, „Zarządzanie Publiczne" (Warszawa), 1(31).

Witte K., Geys B. (2013), Citizen Co-Production and Efficient Public Good Provision: Theory and Evidence from Public Libraries, „European Journal of Operational Research”, 224.

Zawicki M. (2015), Krytyka konceptów fundamentalnych współzarzq̨zania [w:] S. Mazur (red.), Wspótzarzqdzanie publiczne, Wydawnictwo Naukowe Scholar, Warszawa. 